\title{
Pemurnian Biogas untuk meningkatkan Nilai Kalor melalui Adsorpsi Dua Tahap Susunan Seri dengan Media Karbon Aktif
}

\author{
YANTI SUPRIANTI \\ Teknik Konversi Energi Politeknik Negeri Bandung \\ Email: yanti.suprianti@polban.ac.id
}

\begin{abstract}
ABSTRAK
Pemerintah menargetkan peningkatan peran energi terbarukan hingga mencapai 24\% pada tahun 2050. Biogas sebagai salah satu dari sumber energi terbarukan harus memiliki nilai kalor yang memadai agar dapat bersaing dengan sumber energi fosil. Zat yang memiliki kontribusi terbesar dalam menentukan nilai kalor biogas adalah Metana $\left(\mathrm{CH}_{4}\right)$. Namun, biogas juga memiliki kandungan Karbon dioksida $\left(\mathrm{CO}_{2}\right)$ yang bersifat tidak terbakar. Upaya untuk meningkatkan nilai kalor biogas dapat ditempuh dengan menurunkan kandungan $\mathrm{CO}_{2}$, salah satunya melalui proses adsorpsi. Penelitian ini menggunakan kolom adsorpsi seri berukuran 2,43 L untuk meningkatkan waktu kontak antara adsorben karbon aktif dengan gas-gas kontaminan. Hasil penelitian menunjukkan bahwa kandungan $\mathrm{CO}_{2}$ dapat ditekan hingga di bawah $14 \%$ pada waktu adsorpsi 10 menit, dan diperoleh kandungan $\mathrm{CH}_{4}$ hingga minimal 78,73\%. Hasil optimum kinerja kolom adsorpsi seri yaitu pada laju alir 2,4 L/menit dan waktu adsorpsi 10 menit, mampu memurnikan biogas hingga mengandung $\mathrm{CH}_{4} 91,60 \%$. Pada kondisi optimum tersebut, efektifitas kolom adsorpsi adalah sebesar $98,31 \%$.
\end{abstract}

Kata kunci: biogas, pemurnian, karbon aktif, waktu adsorpsi, efektifitas kolom adsorpsi.

\section{ABSTRACT}

Indonesian government had targetted the role of renewable energy, up to $24 \%$ in 2050. Biogas, as one of renewable energy, should have sufficient calorific value in order to be efficiently used and competitive compared to fossil fuels. Methane $\left(\mathrm{CH}_{4}\right)$ in biogas is the most important substance that determine biogas calorific value. On the other hand, another component of biogas, Carbon dioxide $\left(\mathrm{CO}_{2}\right)$, the one that inhibit combustion process must be reduced. One of the methods to reduce $\mathrm{CO}_{2}$ content can be conducted through adsorption process. This research utilized serial adsorption column to increase contact between activated carbon as adsorbent and contaminant gases. The result showed that $\mathrm{CO}_{2}$ content can be suppressed below $14 \%$ in 10 minutes adsorption time, so that $\mathrm{CH}_{4}$ content can be upgraded above $78.73 \%$. The optimum performance of serial adsorption column obtained at $2.4 \mathrm{lpm}$ of biogas flow in 10 minutes adsorption time, able to purify biogas to $91.60 \%$ of $\mathrm{CH}_{4}$ content. In optimum condition, serial adsorption column effectiveness was $98.31 \%$.

Keywords: biogas, purification, activated carbon, adsorption time, serial adsorption column effectiveness. 


\section{PENDAhUlUAN}

Pengembangan energi terbarukan menjadi salah satu fokus pemerintah Indonesia dalam mereduksi ketergantungan terhadap bahan bakar fosil yang cadangannya makin menipis. Menurut data statistik yang diterbitkan oleh Kementerian Energi dan Sumber Daya Mineral melalui Outlook Energi Indonesia 2014, cadangan potensial minyak Indonesia pada tahun 2013 sebesar 3,85 miliar barel sedangkan cadangan terbukti sebesar 3,69 miliar barel. Dan bila tidak ada penemuan cadangan baru, 13 tahun mendatang cadangan minyak bumi di Indonesia akan habis (Outlook Energi Indonesia, 2015). Sementara, menurut sumber yang sama, konsumsi energi final cenderung mengalami peningkatan. Pada rentang tahun 2000-2013, pertumbuhan rata-rata konsumsi energi final adalah sebesar 3,46\%.

Sebagai langkah antisipasi, pemerintah menargetkan untuk mengarahkan bauran energi primer yang dituangkan dalam Kebijakan Energi Nasional pada Peraturan Pemerintah No. 79 Tahun 2014. Bauran energi primer yang ditargetkan Indonesia dapat dilihat pada Gambar 1.

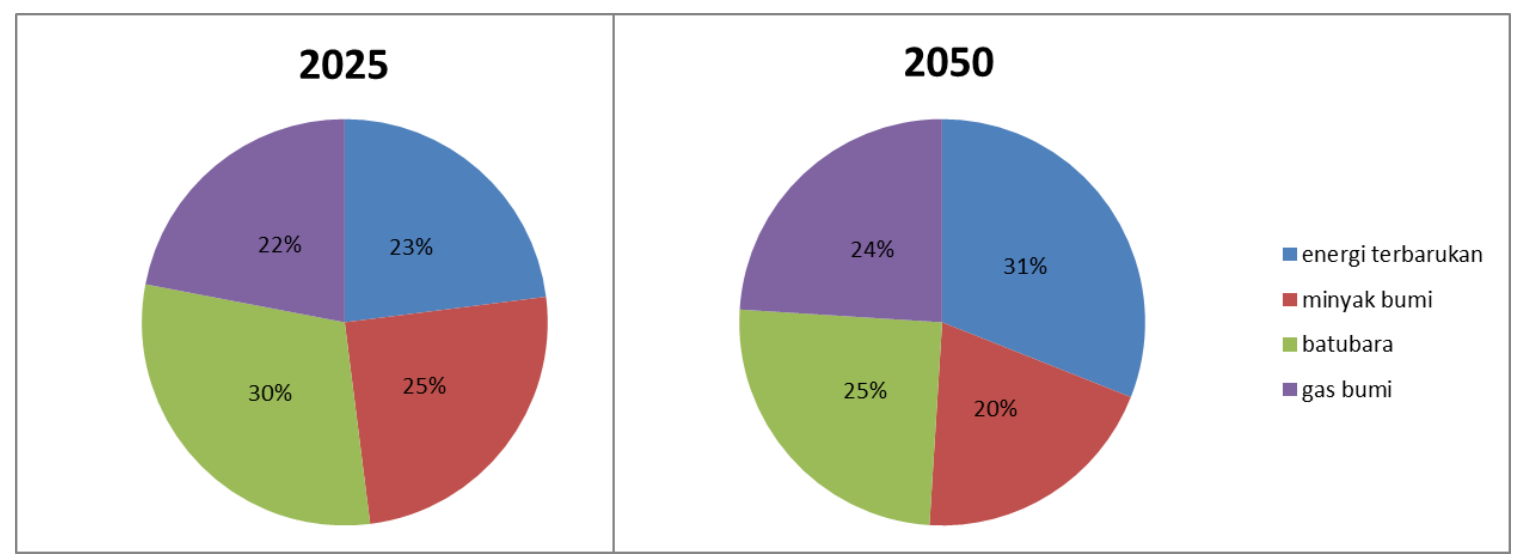

Gambar 1. Bauran Energi Primer Indonesia Tahun 2025 dan 2050 (Sumber: Diolah dari PP No. 79 Tahun 2014)

Seperti terlihat dalam Gambar 1, pemerintah menargetkan peningkatan peran energi terbarukan, dari $22 \%$ pada tahun 2025 hingga mencapai $24 \%$ pada tahun 2050. Salah satu dari sumber energi terbarukan adalah produksi biogas, yang juga memberikan kontribusi pada penurunan emisi gas rumah kaca dan pemeliharaan lingkungan dari sisi pemanfaatan limbah pertanian/peternakan.

Biogas harus memiliki kualitas yang bersaing dengan sumber energi fosil ataupun sumber energi terbarukan lainnya, sehingga dapat digunakan secara efisien. Kualitas ini dapat dilihat melalui nilai kalor yang memadai. Pada umumnya, biogas yang dihasilkan dari fermentasi bahan baku memiliki komposisi yang disajikan dalam Tabel 1. Kandungan biogas yang menentukan nilai kalor adalah gas Metana $\left(\mathrm{CH}_{4}\right)$. Makin tinggi kandungan Metana, semakin tinggi nilai kalor yang terkandung dalam biogas. Dengan komposisi gas yang terdapat dalam Tabel 1, kandungan energi dalam gas tersebut adalah sekira 500-700 Btu/scf. Sedangkan nilai kalor metana sebagai zat murni adalah sekira 1000 Btu/scf. Dengan demikian, peningkatan nilai kalor biogas dapat dilakukan dengan meningkatkan kandungan Metana, dan menurunkan kandungan gas lainnya yang tidak berkontribusi dalam proses pembakaran, seperti gas karbon dioksida $\left(\mathrm{CO}_{2}\right)$. 
Salah satu upaya untuk meningkatkan nilai kalor biogas dapat ditempuh dengan menurunkan kandungan $\mathrm{CO}_{2}$ di dalamnya, sehingga kandungan biogas didominasi hidrokarbon, dalam hal ini $\mathrm{CH}_{4}$. Salah satu upaya menurunkan kandungan $\mathrm{CO}_{2}$ adalah dengan proses adsorpsi.

Tabel 1. Komposisi Biogas Secara Umum (Sumber: Zhang, 2012)

\begin{tabular}{ccc}
\hline Komponen & Rumus Kimia & Komposisi (\%) \\
\hline Metana & $\mathrm{CH}_{4}$ & $50-70$ \\
Karbon dioksida & $\mathrm{CO}_{2}$ & $30-49$ \\
Nitrogen & $\mathrm{N}_{2}, \mathrm{NH}_{3}$ & $0-1$ \\
Hidrogen & $\mathrm{H}_{2}$ & $0-5$ \\
Hidrogen sulfida & $\mathrm{H}_{2} \mathrm{~S}$ & $0,1-0,3$ \\
Air & $\mathrm{H}_{2} \mathrm{O}$ & jenuh \\
\hline
\end{tabular}

Penelitian mengenai penurunan kandungan biogas melalui jalur adsorpsi, telah dilakukan banyak pihak menggunakan jenis adsorben yang berbeda-beda. Hasil penelitian melalui jalur absorpsi biogas menggunakan media larutan $\mathrm{Ca}(\mathrm{OH})_{2}$ menunjukkan penurunan kandungan $\mathrm{CO}_{2}$ hingga mencapai $30 \%$ (Chege dkk., 2014). Sementara melalui jalur adsorpsi dengan media arang aktif $730 \mathrm{~g}$ dan laju biogas $0,025 \mathrm{~L} / \mathrm{s}$ menunjukkan penurunan kadar $\mathrm{CO}_{2}$ sebesar 35,04 \% (Iriani dkk., 2014). Proses adsorpsi ini dilakukan dalam kolom adsorpsi satu tahap, dimana biogas hanya memiliki waktu tinggal yang singkat dalam kolom tersebut.

Untuk keperluan penyediaan biogas yang kontinyu dengan kandungan energi yang memadai, diperlukan usaha lebih lanjut dengan meningkatkan waktu tinggal biogas, sehingga dapat melakukan kontak yang lebih intensif dengan adsorben yang tersedia dan diharapkan lebih banyak $\mathrm{CO}_{2}$ yang terperangkap dalam karbon aktif. Peningkatan waktu tinggal dapat diartikan sebagai peningkatan panjang kolom. Penambahan panjang kolom ini bisa juga diwakili dengan penambahan kolom lain dengan ukuran yang sama yang disusun secara seri. Dengan demikian, kontak intensif dengan waktu tinggal yang lebih lama terjadi antara biogas dan adsorben.

\section{METODOLOGI}

Kolom adsorpsi dibuat dari pipa PVC kelas AW berukuran 2,5 inchi, yang dilengkapi dengan peralatan penunjang aliran gas. Adapun adsorben yang digunakan adalah karbon aktif berbahan dasar batok kelapa. Sebelum digunakan, adsorben diberi pra perlakuan terlebih dahulu, yaitu pemanasan di dalam oven selama 1 jam, dengan temperatur pemanasan 300 ${ }^{\circ} \mathrm{C}$, yang bertujuan untuk menyiapkan kondisi adsorben hingga siap pakai. Bahan baku berupa biogas diambil dari digester biogas di peternakan milik warga di Desa Tugu Mukti, Cisarua Lembang. Bahan baku pembuatan biogas berasal dari kotoran sapi yang didekomposisi di dalam biodigester fiber bervolume $4 \mathrm{~m}^{3}$. Adapun biogas yang dihasilkan dari digester memiliki tekanan $7,45 \mathrm{kPa}$. Kondisi lingkungan pada saat pengambilan sampel yaitu pada temperatur $24 \pm 1{ }^{\circ} \mathrm{C}, 655 \pm 2 \mathrm{mmHg}$ dan kelembapan relatif rata-rata $63,4 \pm 8 \%$. Saat ini, biogas yang dihasilkan baru digunakan untuk kebutuhan rumah tangga, seperti memasak. 
Kolom adsorpsi terbagi menjadi dua bagian (Gambar 2), yaitu bagian masukan biogas dan bagian adsorpsi yang berisi adsorben penuh. Kedua bagian tersebut dibatasi oleh ram nyamuk, yang berguna sebagai saringan untuk meyangga agar karbon aktif tidak jatuh area masukan biogas. Gas dialirkan masuk ke kolom dari arah bawah dan keluar melalui saluran di atas kolom. Konfigurasi pengujian alat adsorpsi biogas ditunjukkan pada Gambar 3.

Material : Pipa PVC kelas AW

Tekanan Max : 9,8 bar (wavin.co.id)

Diameter luar : 2 1/2" $(7,6 \mathrm{~cm})$

Diameter dalam : $7 \mathrm{~cm}$

Tinggi ruang adsorber : $50 \mathrm{~cm}$

Volume ruang adsorber : 1,92 liter

Tinggi kolom total : $63 \mathrm{~cm}$

Volume kolom total : 2,43 liter

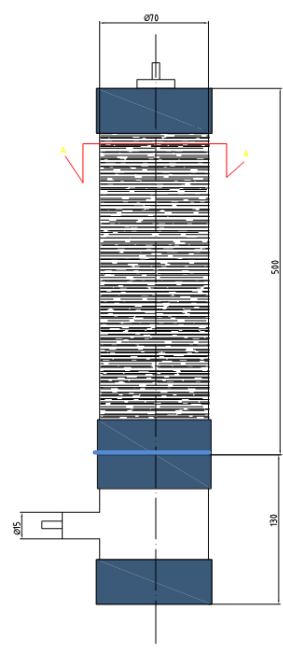

Gambar 2. Spesifikasi Kolom Adsorpsi

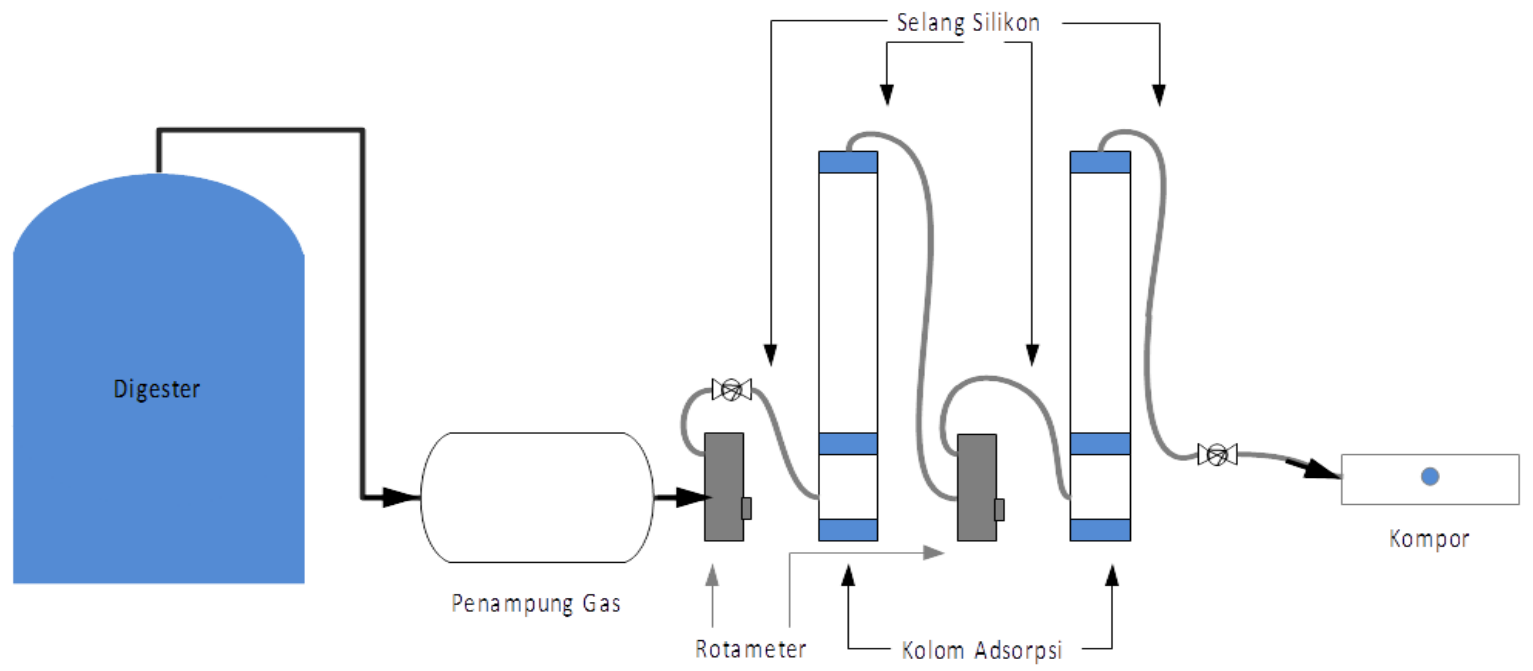

Gambar 3. Skema Instalasi Pemurnian Biogas

Pada proses adsorpsi, gas dilewatkan melalui kolom adsorpsi dua tahap dengan susunan seri. Adapun karbon aktif diisikan ke dalam kolom hingga memenuhi kolom. Untuk mendapatkan profil yang komprehensif, proses pengambilan sampel dilakukan tiga (3) kali pengambilan sampel untuk setiap titik pengukuran yang sama dengan jeda waktu 5 menit untuk setiap pengambilan sampel. Hal ini dilakukan untuk melihat perubahan kondisi biogas sumber dari digester dan juga kondisi biogas setelah melewati kolom adsorpsi. 
Pengambilan sampel dilakukan di tiga (3) titik, yaitu:

a. Pada aliran biogas yang menjadi input kolom adsorpsi pertama, untuk menguji komposisi biogas sumber.

b. Pada aliran keluaran kolom adsorpsi pertama, yang juga menjadi input kolom adsorpsi ke-dua, untuk mengidentifikasi komposisi biogas setelah mengalami proses adsorpsi, sekaligus untuk mengetahui kinerja kolom adsorpsi satu tahap.

c. Pada aliran keluaran kolom adsorpsi yang ke-dua, untuk menguji komposisi biogas setelah mengalami proses adsorpsi dua tahap, dan sekaligus untuk mengetahui kinerja kolom adsorpsi dua tahap susunan seri.

Pengujian ini dilakukan dengan memvariasikan 5 (lima) laju alir biogas, yaitu 1,8 L/menit, 2,1 L/menit, 2,4 L/menit, 2,7 L/menit dan $3 \mathrm{~L} /$ menit. Setiap perubahan laju alir, dilakukan penggantian adsorben karbon aktif agar awal kolom bekerja pada kondisi yang sama.

Sampel diambil dengan menggunakan suntikan (syringe) yang juga berfungsi sebagai penampung sampel biogas yang akan diuji komposisinya. Sampel, baik biogas sebelum proses adsorpsi, maupun setelah proses adsorpsi, dibawa dan diukur komposisinya menggunakan alat Gas Chromatography (GC). Hasil uji adalah berupa komposisi gas-gas $\mathrm{CH}_{4}, \mathrm{CO}_{2}, \mathrm{H}_{2}$, dan $\mathrm{N}_{2}$.

\section{HASIL DAN PEMBAHASAN}

\subsection{Kandungan Biogas Sebelum Pemurnian}

Berdasarkan Gambar 4, kandungan biogas sumber menunjukkan kondisi yang berbeda. Pengambilan sampel biogas sumber dilakukan untuk setiap laju alir input kolom adsorpsi pertama, dan dilakukan dalam 3 kali pengambilan, yaitu pada menit ke-0, menit ke-5 dan menit ke-10. Hasil uji kandungan biogas dari setiap sampel mengandung $\mathrm{CH}_{4}$, sebagai gas yang diinginkan, dan juga gas-gas yang akan dihilangkan dalam proses adsorpsi, yaitu $\mathrm{CO}_{2}$, dan gas lainnya, seperti $\mathrm{N}_{2}, \mathrm{H}_{2}$, dan $\mathrm{O}_{2}$. Gas $\mathrm{CO}_{2}$ merupakan gas utama yang ingin dihilangkan dari aliran biogas. Terlihat bahwa untuk laju alir yang sama, menunjukkan kecenderungan peningkatan kandungan $\mathrm{CH}_{4}$ seiring waktu. Pada menit ke-10, kandungan $\mathrm{CH}_{4}$ merupakan yang tertinggi di hampir setiap laju alir, kecuali laju 1,8 L/menit dan 2,1 $\mathrm{L} /$ menit. Sementara untuk gas $\mathrm{CO}_{2}$, terjadi penurunan kandungan seiring waktu. $\mathrm{Hal}$ ini mengindikasikan bahwa gas-gas selain $\mathrm{CH}_{4}$ tersebut telah terlebih dahulu mengalir menuju ke kolom adsorpsi. 


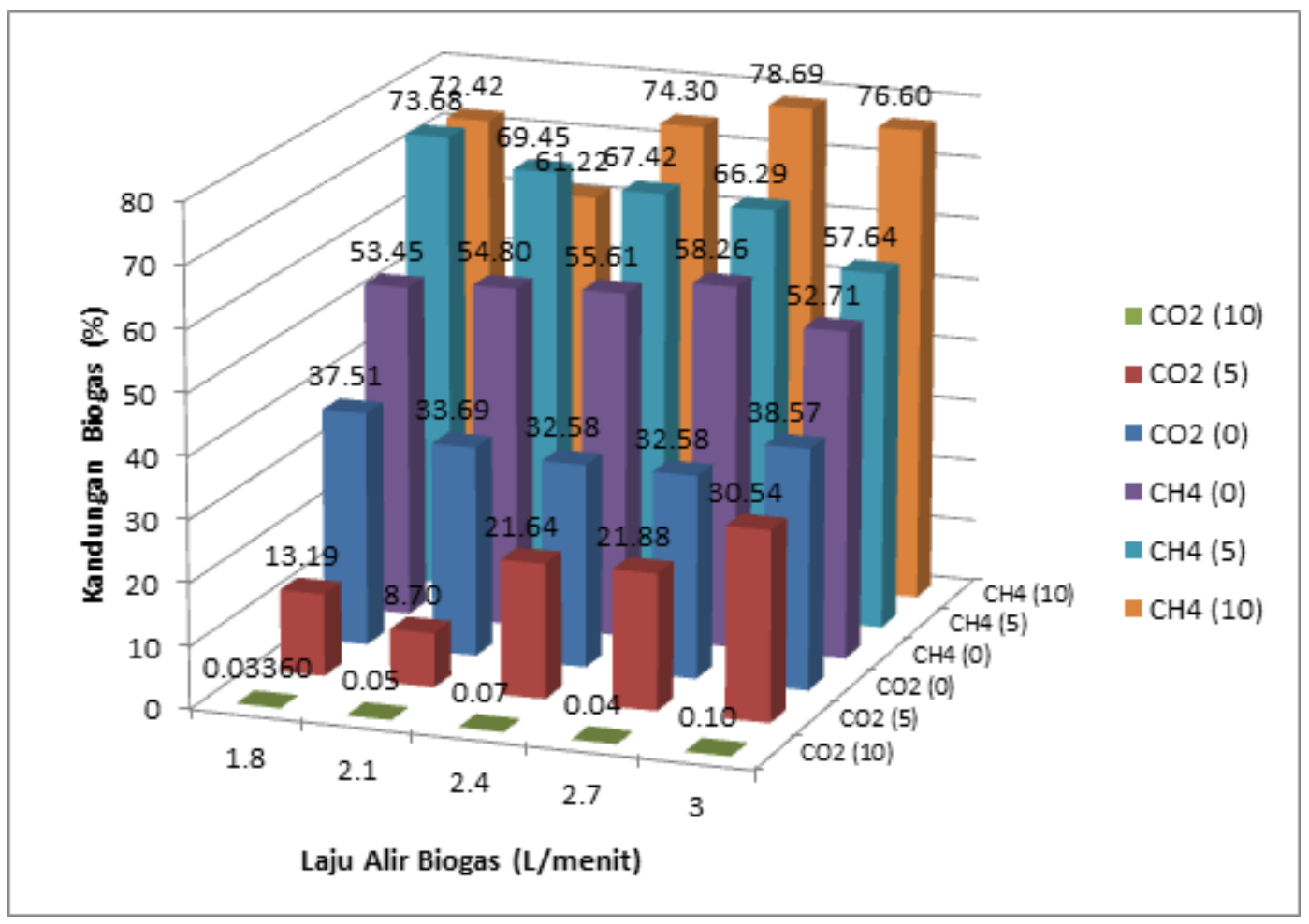

Gambar 4. Komposisi Biogas Sumber

Bila dilihat hasil uji sampel pada menit ke-0, kandungan $\mathrm{CO}_{2}$ dalam biogas berada pada rentang 32-39\%. Hal ini menunjukkan bahwa biogas memang perlu penanganan untuk menghilangkan kandungan $\mathrm{CO}_{2}$ tersebut. Sementara kandungan $\mathrm{CO}_{2}$ pada menit ke-10 sudah sangat kecil, antara 0,03-0,1\%. Hal ini menunjukkan bahwa pada menit ke-10 biogas sudah pada kondisi yang baik untuk digunakan, tentunya setelah melewati kolom adsorpsi.

\subsection{Hasil Kandungan Biogas setelah Pemurnian}

Pemurnian biogas dilakukan dalam alat adsorpsi dua tahap, yang diwakili oleh dua kolom seri dengan media adsorben karbon aktif. Untuk mendeteksi perubahan yang terjadi pada tiap kolom, maka selain pada sumber biogas, pengukuran dilakukan pada keluaran kolom tunggal (setelah melewati kolom pertama) dan keluaran kolom seri (setelah melewati kolom ke-2). Analisis hasil pemurnian biogas difokuskan pada kandungan $\mathrm{CH}_{4}$ sebagai sumber energi, dan penurunan kandungan $\mathrm{CO}_{2}$ sebagai kontaminan utama penghambat pembakaran.

\subsubsection{Kolom Adsorpsi Tunggal}

Berdasarkan Gambar 5 (kiri), peningkatan laju alir cenderung meningkatkan kandungan $\mathrm{CH}_{4}$ keluaran kolom adsorpsi tunggal, baik pada menit ke-0 maupun menit ke-10, namun di menit ke-5 terjadi fluktuasi kandungan $\mathrm{CH}_{4}$ seiring peningkatan laju alir. Peningkatan kandungan $\mathrm{CH}_{4}$ menunjukkan bahwa gas-gas lain yang menjadi kontaminan telah terperangkap di dalam media adsorpsi, yaitu karbon aktif. Makin meningkatnya laju alir menyebabkan semakin banyak pula gas-gas yang terperangkap di adsorben karbon aktif.

Dari pengamatan yang dilakukan pada tiga variasi waktu, terlihat bahwa terjadi peningkatan kandungan $\mathrm{CH}_{4}$ keluaran kolom tunggal. Hal ini menunjukkan bahwa dibutuhkan waktu yang cukup untuk mencapai kinerja optimal dari kolom adsorpsi. Pengamatan sesaat pada menit 
ke-0 belum dapat menunjukkan kemampuan atau kinerja alat yang terbaik, karena proses adsorpsi masih meningkat menuju kondisi yang lebih optimal.

Sebenarnya apabila dilihat dari data sampel, masih terdapat peluang untuk meningkatkan waktu pengamatan menjadi lebih lama, sehingga dapat diperoleh kondisi waktu optimal adsorpsi, bahkan sampai menunjukkan penurunan kinerja alat, yang menunjukkan kondisi adsorben menuju kejenuhan. Akan tetapi, bila dilihat pada Gambar 5 (kanan) kandungan $\mathrm{CO}_{2}$ hasil uji sampel menit ke-0, peningkatan laju alir memberikan kecenderungan fluktuasi kandungan $\mathrm{CO}_{2}$ yang cenderung parabolik. Artinya nilai kandungan $\mathrm{CO}_{2}$ tinggi di laju alir terkecil dan laju alir terbesar. Hal ini menunjukkan kemampuan adsorpsi dari media adsorben mencapai optimal pada variasi laju alir di tengah. Namun, hasil uji di menit ke-0 belum dapat disimpulkan, karena proses adsorpsi masih menunjukkan peningkatan seiring semakin lama waktu pengamatan.
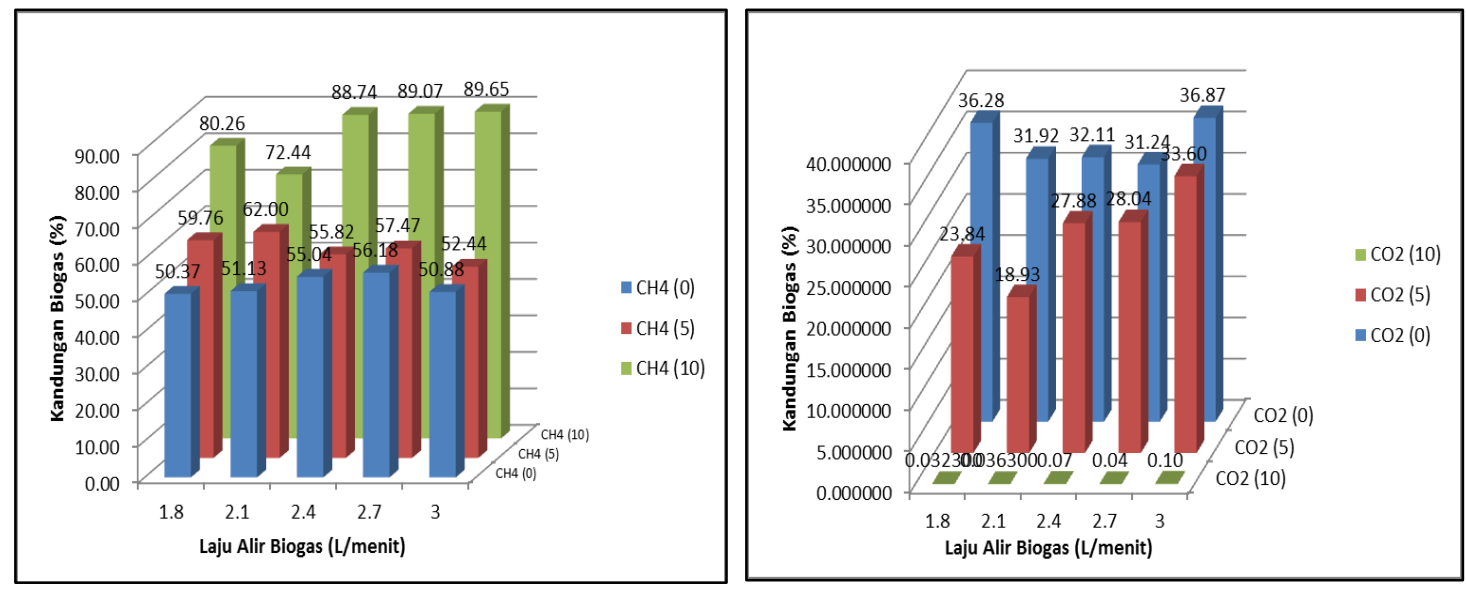

Gambar 5. Hasil Uji Kandungan $\mathrm{CH}_{4}$ dan $\mathrm{CO}_{2}$ dalam Biogas Keluaran Kolom Tunggal

Hasil uji di menit ke-5 dan menit ke-10 menunjukkan bahwa makin cepat laju alir biogas, kandungan $\mathrm{CO}_{2}$ keluaran kolom adsorpsi tunggal cenderung semakin meningkat. Hal ini mengindikasikan penambahan laju alir tidak serta merta menyebabkan adsorpsi $\mathrm{CO}_{2}$ di media karbon aktif. Kemungkinan bertambahnya laju alir mendorong $\mathrm{CO}_{2}$ hanya melewati ruang kosong di antara sela-sela butiran karbon aktif, sehingga tidak terperangkap di dalam pori-porinya. Kemungkinan lain adalah media karbon aktif telah terlebih dahulu menyerap gas-gas lain selain $\mathrm{CO}_{2}$.

Bila dibandingkan waktu pengamatan antara menit ke-0, menit ke-5 dan menit ke-10, terlihat bahwa semakin lama proses adsorpsi terjadi, penurunan kandungan $\mathrm{CO}_{2}$ sangat signifikan terjadi pada menit ke-10. Hal ini menunjukkan pada menit ke-10 proses adsorpsi sudah mencapai kondisi optimal. Hal ini pun sejalan dengan penelitian yang dilakukan oleh Heru Susanto (Susanto, 2013), bahwa peningkatan waktu adsorpsi dapat meningkatkan adsorpsi $\mathrm{CO}_{2}$ sehingga kandungannya semakin menurun.

\subsubsection{Kolom Adsorpsi Seri}

Hasil uji sampel setelah melewati dua kolom adsorpsi yang dipasang seri ditunjukkan pada Gambar 6. Disini terlihat bahwa peningkatan laju alir menyebabkan peningkatan kandungan $\mathrm{CH}_{4}$ keluaran kolom adsorpsi seri. Namun, pada laju alir tertentu mengalami penurunan kembali. Hal ini menunjukkan bahwa kolom adsorpsi seri memiliki kinerja optimal pada laju alir tertentu, yaitu di laju alir 2,4 L/menit. 
Bila melihat variasi waktu, di menit ke-0 dan menit ke-5, kandungan $\mathrm{CH}_{4}$ tertinggi terjadi pada laju 2,7 L/menit, yaitu berturut-turut 56,99\% dan 58,77\% (Gambar 6 kiri). Sementara di menit ke-10 kandungan $\mathrm{CH}_{4}$ tertinggi terjadi pada laju alir 2,4 L/menit, yaitu 91,06\%. Pada menit ke-10 ini diasumsikan proses adsorpsi sudah mulai optimal, sehingga dapat dikatakan bahwa kandungan biogas terbaik, terjadi di laju alir 2,4 L/menit. Hal ini melihat aspek kandungan $\mathrm{CH}_{4}$ tertinggi pada laju alir optimal pemurnian biogas dengan jalur adsorpsi seri.

Gambar 6 juga menunjukkan bahwa peningkatan waktu adsorpsi meningkatkan kandungan $\mathrm{CH}_{4}$. Hal ini sejalan dengan kondisi di kolom adsorpsi tunggal, bahwa semakin lama waktu pengamatan (waktu adsorpsi) maka proses menuju kondisi optimal.
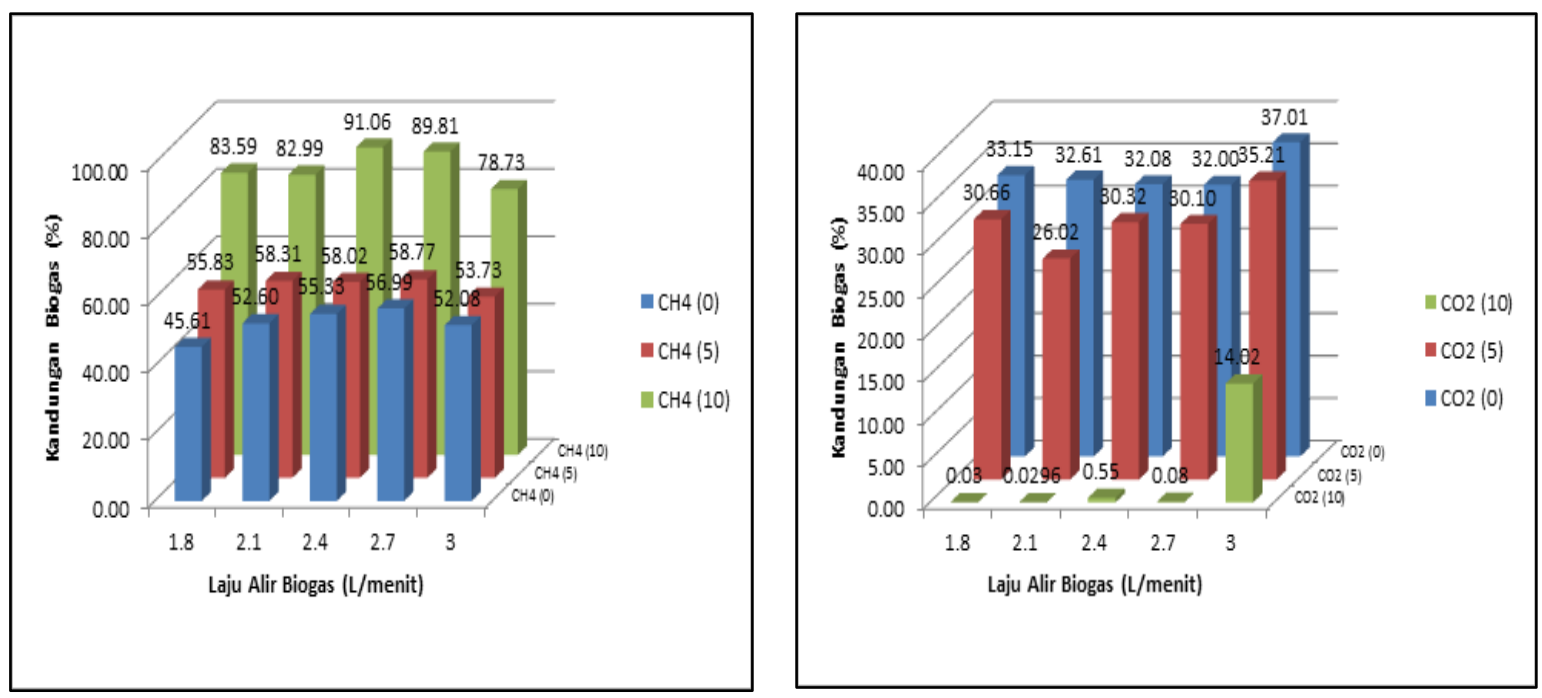

\section{Gambar 6. Hasil Uji Kandungan $\mathrm{CH}_{4}$ dan $\mathrm{CO}_{2}$ dalam Biogas Keluaran Kolom Seri}

Hasil uji kandungan $\mathrm{CO}_{2}$ dalam biogas keluaran kolom adsorpsi seri pada Gambar 6 (kanan) menunjukkan bahwa semakin tinggi laju alir menyebabkan kandungan $\mathrm{CO}_{2}$ meningkat kembali, setelah mengalami penurunan. Hal ini menunjukkan bahwa kinerja optimal kolom adsorpsi untuk menyerap $\mathrm{CO}_{2}$ telah terlewati. Peristiwa ini terjadi pada menit ke-0 dan menit ke-10, yaitu peningkatan kembali terjadi pada laju alir tertinggi, yaitu $3 \mathrm{~L} / \mathrm{menit}$. Sementara di menit ke-5, kandungan $\mathrm{CO}_{2}$ terkecil adalah saat laju alir 2,1 L/menit.

Bila diamati berdasarkan waktu pengamatan, maka pada menit ke-10 kandungan $\mathrm{CO}_{2}$ berada pada nilai terendah. Seperti telah dijelaskan pada bahasan sebelumnya, bahwa peningkatan waktu adsorpsi mengantarkan pada kondisi yang lebih optimal untuk mengadsorpsi gas kontaminan, dalam hal ini adalah $\mathrm{CO}_{2}$. Nilai terendah ini terjadi pada laju alir 2,1 L/menit, yaitu $0,0296 \%$.

Walaupun kondisi kandungan $\mathrm{CO}_{2}$ ini terkecil di laju alir 2,1 L/menit, bila digabungkan dengan data kandungan $\mathrm{CH}_{4}$ yang terbesar (91,06\%) terjadi pada laju alir 2,4 L/menit, maka kondisi yang lebih diinginkan adalah kondisi biogas dengan nilai kalor yang baik, yang ditandai dengan kandungan $\mathrm{CH}_{4}$ yang tinggi. Pada laju alir tersebut, kandungan $\mathrm{CO}_{2}$ pun sudah sangat kecil, yaitu $0,55 \%$. 


\subsection{Efektifitas Adsorpsi $\mathrm{CO}_{2}$}

Efektifitas adsorpsi menyatakan tingkat kemampuan alat dalam mengadsorpsi $\mathrm{CO}_{2}$, yang diformulasikan sebagai berikut (Iriani, 2014):

Efektifitas Adsorpsi $\mathrm{CO}_{2}=\frac{\left(\text { kandungan } \mathrm{CO}_{2} \text { awal }- \text { kandungan } \mathrm{CO}_{2} \text { akhir }\right)}{\text { kandungan } \mathrm{CO}_{2} \text { awal }} \times 100 \%$

Tabel 2. Kandungan $\mathrm{CO}_{2}$ Sebelum dan Setelah Pemurnian

\begin{tabular}{|c|c|c|c|c|c|c|}
\hline \multirow{2}{*}{$\begin{array}{l}\text { Laju alir } \\
\text { (L/menit) }\end{array}$} & \multirow{2}{*}{$\begin{array}{c}\text { Waktu } \\
\text { (menit ke) }\end{array}$} & \multicolumn{3}{|c|}{ Kandungan $\mathrm{CO}_{2}(\%)$} & \multicolumn{2}{|c|}{ Efektifitas (\%) } \\
\hline & & Sumber & $\begin{array}{c}\text { Kolom } \\
\text { Tunggal }\end{array}$ & $\begin{array}{c}\text { Kolom } \\
\text { Seri }\end{array}$ & Kolom Tunggal & Kolom Seri \\
\hline \multirow{3}{*}{1,8} & 0 & 37,51 & 36,28 & 33,15 & $3,29 \%$ & $11,61 \%$ \\
\hline & 5 & 13,19 & 23,84 & 30,66 & $36,44 \%$ & $18,27 \%$ \\
\hline & 10 & 0,03 & 0,03 & 0,03 & $99,91 \%$ & $99,97 \%$ \\
\hline \multirow{3}{*}{2,1} & 0 & 33,69 & 31,92 & 32,61 & $5,27 \%$ & $3,22 \%$ \\
\hline & 5 & 8,70 & 18,93 & 26,02 & $43,82 \%$ & $22,78 \%$ \\
\hline & 10 & 0,05 & 0,04 & 0,03 & $99,89 \%$ & $99,91 \%$ \\
\hline \multirow{3}{*}{2,4} & 0 & 32,58 & 32,11 & 32,08 & $1,42 \%$ & $1,53 \%$ \\
\hline & 5 & 21,64 & 27,88 & 30,32 & $14,40 \%$ & $6,91 \%$ \\
\hline & 10 & 0,07 & 0,07 & 0,55 & $99,79 \%$ & $98,31 \%$ \\
\hline \multirow{3}{*}{2,7} & 0 & 32,59 & 31,24 & 32,00 & $4,11 \%$ & $1,79 \%$ \\
\hline & 5 & 21,88 & 28,04 & 30,10 & $13,96 \%$ & $7,63 \%$ \\
\hline & 10 & 0,04 & 0,04 & 0,08 & $99,89 \%$ & $99,75 \%$ \\
\hline \multirow{3}{*}{3,0} & 0 & 38,57 & 36,87 & 37,01 & $4,42 \%$ & $4,03 \%$ \\
\hline & 5 & 30,54 & 33,60 & 35,21 & $12,90 \%$ & $8,70 \%$ \\
\hline & 10 & 0,10 & 0,10 & 14,02 & $99,75 \%$ & $63,65 \%$ \\
\hline
\end{tabular}

Dari Tabel 2, terlihat penerapan waktu adsorpsi selama 10 menit dapat menurunkan kandungan $\mathrm{CO}_{2}$ ke nilai yang sangat kecil, sehingga pada waktu ini pengaruh laju alir menjadi sangat kecil, terlihat dari nilai efektifitas, baik pada kolom adsorpsi tunggal, maupun pada kolom adsorpsi seri, yang hampir seluruhnya menunjukkan efektifitas penyerapan $\mathrm{CO}_{2}$ yang sangat baik.

Efektifitas penyerapan $\mathrm{CO}_{2}$ yang terkecil hanya pada kolom seri dengan laju alir $3 \mathrm{~L} /$ menit $(63,65 \%)$. Walaupun kandungan $\mathrm{CO}_{2}$ di keluaran kolom tunggal sudah menunjukkan nilai $0,10 \%$, namun terjadi peningkatan lagi menjadi $14,02 \%$. Hal ini mungkin disebabkan pada kolom adsorpsi ke-2, gas yang diserap oleh karbon aktif adalah gas-gas lain selain $\mathrm{CO}_{2}$, sehingga mengakibatkan persentase kandungan $\mathrm{CO}_{2}$ terhadap keseluruhan aliran biogas menjadi lebih tinggi.

Pada laju alir 1,8 dan 2,1 L/menit, efektifitas kolom adsorpsi seri sedikit lebih baik dibandingkan dengan kolom adsorpsi tunggal. Namun, untuk laju alir yang lebih tinggi, hal ini tidak terjadi. Dengan demikian, pada waktu 10 menit, hal yang menunjukkan keunggulan pemurnian bukanlah dari efektifitas penyerapan $\mathrm{CO}_{2}$, tapi dapat dilihat dari aspek lain, yaitu dampaknya terhadap nilai kalor. 


\subsection{Nilai Kalor Biogas}

Nilai kalor biogas dinyatakan oleh seberapa besar kandungan $\mathrm{CH}_{4}$ dalam biogas. Makin tinggi kandungan $\mathrm{CH}_{4}$, semakin besar kandungan energi (nilai kalor) pada biogas, dan sebaliknya, makin kecil kandungan $\mathrm{CH}_{4}$, semakin kecil nilai kalornya (Chisti, 2008).

Pengamatan nilai kalor diambil pada kondisi biogas keluar kolom seri dengan waktu adsorpsi 10 menit. Dalam Gambar 7 terlihat bahwa nilai kalor biogas setelah pemurnian menggunakan kolom tunggal, telah menunjukkan nilai yang baik, dan cenderung meningkat dengan peningkatan laju alir. Namun setelah melewati kolom adsorpsi seri, terjadi kondisi optimal, dimana nilai kandungan $\mathrm{CH}_{4}$ tertinggi terjadi pada laju alir 2,4 L/menit. Dengan demikian, nilai kalor terbaik juga diperoleh pada kondisi tersebut, yaitu kandungan $\mathrm{CH}_{4}$ sebesar $91,06 \%$.

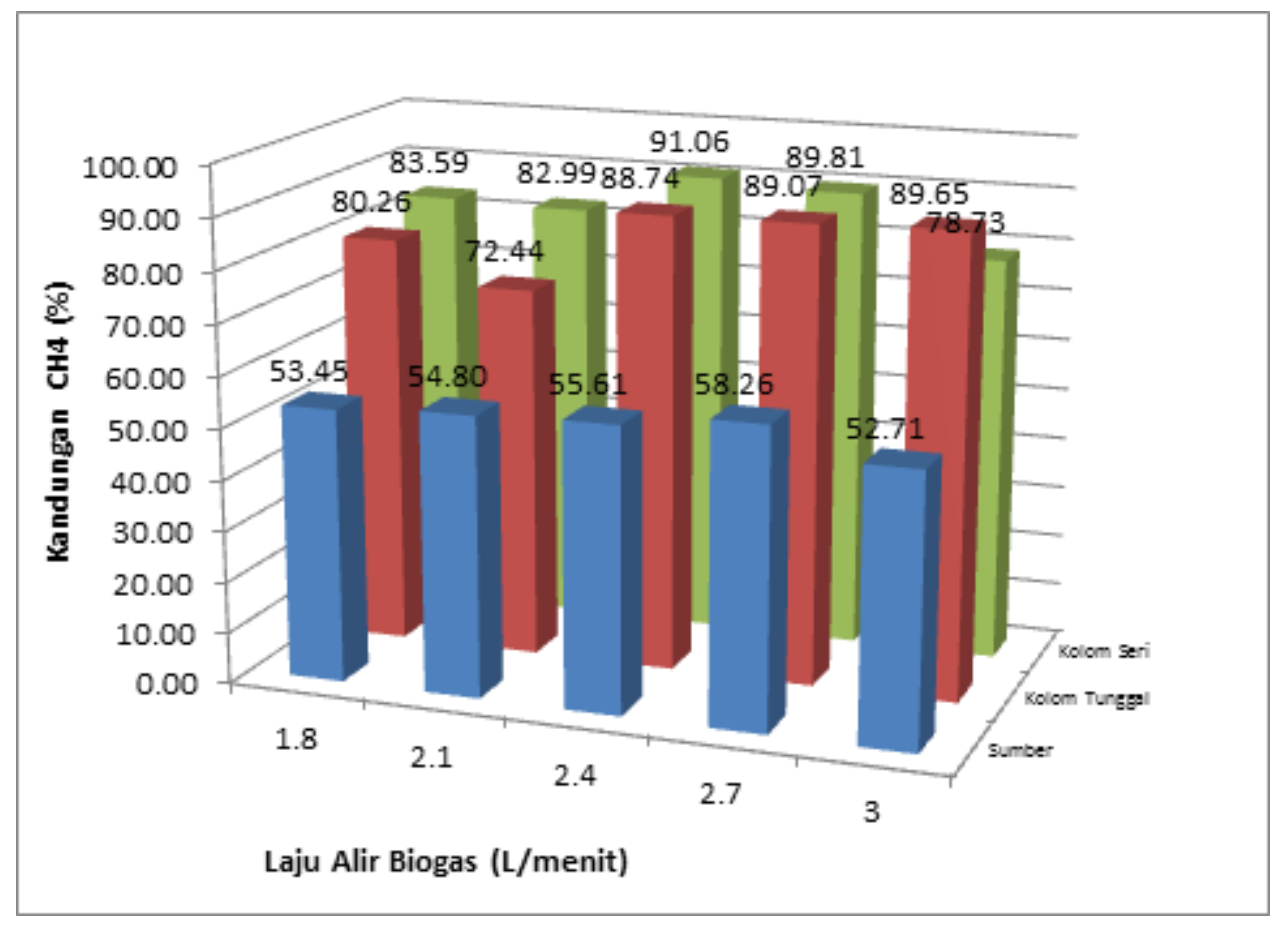

Gambar 7. Kandungan $\mathrm{CH}_{4}$ Sebelum dan Sesudah Pemurnian

Dengan nilai kalor $\mathrm{CH}_{4}$ sebesar $50.020 \mathrm{~kJ} / \mathrm{kg}$ (Moran, 2004), dan densitas $\mathrm{CH}_{4}$ sebesar $0,656 \mathrm{~kg} / \mathrm{m}^{3}$, maka terhitung untuk kandungan $\mathrm{CH}_{4} 91,06 \%$, nilai kalor biogas diperoleh sebesar $29.878,84 \mathrm{~kJ} / \mathrm{m}^{3}$.

Nilai kalor biogas $=$ nilai kalor $\mathrm{CH}_{4}$ acuan $x$ densitas $\mathrm{CH}_{4} \times$ kandungan $\mathrm{CH}_{4}$ dalam biogas

$$
\left(\frac{\mathrm{kJ}}{\mathrm{m} 3}\right) \quad\left(\frac{\mathrm{kJ}}{\mathrm{kg}}\right) \quad x \quad\left(\frac{\mathrm{kg}}{\mathrm{m} 3}\right) x
$$


Tabel 3. Kandungan $\mathrm{CH}_{4}$ dan Nilai Kalornya

\begin{tabular}{|c|c|c|c|c|c|c|}
\hline \multirow{2}{*}{$\begin{array}{c}\text { Laju alir } \\
\text { (L/menit) }\end{array}$} & \multicolumn{3}{|c|}{ Kandungan $\mathbf{C H}_{\mathbf{4}}(\%)$} & \multicolumn{3}{c|}{ Nilai Kalor Biogas $\left(\mathbf{k J} / \mathbf{m}^{\mathbf{3}}\right)$} \\
\cline { 2 - 7 } & Sumber & $\begin{array}{c}\text { Kolom } \\
\text { Tunggal }\end{array}$ & $\begin{array}{c}\text { Kolom } \\
\text { Seri }\end{array}$ & Sumber & $\begin{array}{c}\text { Kolom } \\
\text { Tunggal }\end{array}$ & $\begin{array}{c}\text { Kolom } \\
\text { Seri }\end{array}$ \\
\hline 1,8 & 53,45 & 80,26 & 83,59 & 17537,37 & 26336,93 & 27429,54 \\
\hline 2,1 & 54,80 & 72,44 & 82,99 & 17982,02 & 23769,1 & 27233,18 \\
\hline 2,4 & 55,61 & 88,74 & 91,06 & 18246,59 & 29118,89 & $\mathbf{2 9 8 7 8 , 8 4}$ \\
\hline 2,7 & 58,26 & 89,07 & 89,81 & 19118,20 & 29225,66 & 29469,82 \\
\hline 3,0 & 52,71 & 89,65 & 78,73 & 17296,55 & 29415,62 & 25833,47 \\
\hline
\end{tabular}

\section{KESIMPULAN}

Dari penelitian ini dapat disimpulkan bahwa :

1. Kandungan $\mathrm{CO}_{2}$ untuk setiap laju alir, diperoleh pada nilai di bawah $14 \%$ untuk waktu adsorpsi 10 menit.

2. Kandungan $\mathrm{CH}_{4}$ tertinggi untuk setiap laju alir, diperoleh pada nilai di atas $78 \%$ untuk waktu adsorpsi 10 menit.

3. Hasil optimum untuk kolom adsorpsi seri diperoleh pada laju alir 2,4 L/menit dan waktu adsorpsi 10 menit, dengan nilai kalor biogas tertinggi, yaitu 91,60\%.

4. Komposisi biogas pada saat optimum adalah: $91,6 \% \mathrm{CH}_{4}, 0,55 \% \mathrm{CO}_{2}, 6,41 \% \mathrm{~N}_{2}$, dan $1,99 \% \mathrm{O}_{2}$.

5. Pada kondisi optimum, efektifitas kolom adsorpsi seri adalah sebesar $98,31 \%$.

\section{UCAPAN TERIMA KASIH}

Penulis mengucapkan terima kasih kepada Politeknik Negeri Bandung yang telah mendanai penelitian ini.

\section{DAFTAR RUJUKAN}

BPPT. (2015). Outlook Energi Indonesia 2015. Pengembangan Energi untuk Mendukung Pembangunan Berkelanjutan. Pusat Teknologi Pengembangan Sumberdaya Energi Badan Pengkajian dan Penerapan Teknologi.

Chege, J., M., Bernard W. Ikua. Mwangi Njogu. Neri Kahiu. (2014). Studies on Adsorption Biogas Purification Reactor for Domestic Sized Digesters in Kenya. International Journal of Innovative Scientific \& Engineering Technologies Research. 2 (2).

Chisti, Y. (2008). Biodiesel from Microalgae Beats Bioethanol. Trends Bioethanol. Volume (26): $126-131$.

Dewan Energi Nasional. (2014). Outlook Energi Indonesia 2014. Kementerian Energi dan Sumber Daya Mineral. Jakarta.

Iriani, P., Heryadi, A. (2014). Pemurnian Biogas Melalui Kolom Beradsorben Karbon Aktif. SIGMA-MU. 6(2). 
Moran, Michael, J., Howard, N., Shapiro, Daisie D. Boettner, Margaret B. Bailey. (2014). Fundamentals of Engineering Thermodynamics $8^{\text {th }}$ Edition. Wiley.

Republik Indonesia. (2014). Peraturan Pemerintah Republik Indonesia No. 79 Tahun 2014 tentang Kebijakan Energi Nasional. Lembaran Negara RI Tahun 2014, No. 300. Kementerian Hukum dan Hak Asasi manusia. Jakarta.

Susanto, H. (2013). Modifikasi Karbon Aktif sebagai Adsorben untuk Pemurnian Biogas. Ejournal Universitas Diponegoro.

Zhang, R. (2012). Biogas Production Technologies. Biogas and Fuel Cell Workshop. National Renewable Energy Laboratory. 